CESIS Electronic Working Paper Series

Paper No. 312

Taxes, tax administrative burdens and new firm formation

\author{
Pontus Braunerhjelm \\ Johan E. Eklund
}

May, 2013 


\title{
Taxes, tax administrative burdens and new firm formation
}

\author{
Pontus Braunerhjelm \\ Swedish Entrepreneurship Forum and Royal Institute of Technology \\ E-mail: pontus.braunerhjelm@entreprenorskapsforum.se
}

Phone: +46-72-9565569

Johan E. Eklund*

Swedish Entrepreneurship Forum and Jönköping International Business School

E-mail: johan.eklund@entreprenorskapsforum.se

Phone: +46-70-6591046

${ }^{*}$ Corresponding author

\begin{abstract}
:
This paper examines the tax administrative burden and its effect on new firm formation. It is well recognized that entrepreneurship and new firm formation are critical factors in determining economic growth and development. New firm entry into the marketplace enhances welfare in two distinct ways: 1) by promoting innovation, productivity and economic growth and 2) by increasing competition, which lowers prices and expands output. It is also well documented that barriers to entry reduce the likelihood that new firms will enter various sectors. We argue that the burden imposed by tax codes and tax compliance constitutes a barrier to entry that has been neglected in the previous literature. We use data from the World Bank to measure the administrative burden that the complexity of tax policy imposes on new firm. Additionally, we use a measure of new firm formation-entry density. Our data cover 118 countries over a period of six years. We find that the entry rate is significantly reduced by the tax administrative burden and that this effect is unrelated to general taxes on corporate profits and is robust to the inclusion of several important control variables.
\end{abstract}

JEL-codes: K20, L26, L51, D22, H20.

Keywords: tax administrative burden, entry, entrepreneurship, new firm formation, regulations, tax policy 


\section{Acknowledgments:}

We gratefully acknowledge the financial support received from the Marianne and Marcus Wallenberg Foundation. We are also grateful for comments on this paper from seminar participants at the Swedish Ministry of Finance. 
1. Introduction

Regulations have been shown to deter growth, particularly through their effects on new firm formation, competition and innovation (Aghion et al. 2006, Ciccone and Papaionnou 2006, Ardagna and Lusardi 2009), and start-up costs are considerably higher in more regulated economies (Fonseca et al. 2001, 2007). ${ }^{1}$ However, even firms that are simply copying incumbents tend to generate higher productivity, innovation and falling prices (Andersson et al. 2011). Similarly, recent studies indicate that regulatory reform results in higher rates of market entry by new firms (Klapper and Love, 2011).

Regulation not only influences the direct costs of entering a market but also leads to substantial indirect effects that tend to deter entry. As shown by Ciccone and Papaioannou (2006), Klapper et al. (2006) and Ardagna and Lusardi (2008), the positive effects that are associated with skills (education) diminish considerably in more regulated countries, particularly for opportunity-based entrepreneurship. Similarly, the positive effects of knowing people who are entrepreneurs-thus, having an entrepreneurial network and belonging to an entrepreneurial culture-also tend to be reduced in such countries. This effect appears to prevail primarily with respect to opportunity- and innovation-based entrepreneurship. Hence, the direct and indirect effects that are associated with regulatory burdens appear to decelerate the forces of

\footnotetext{
${ }^{1}$ The reasons for regulations have been attributed to "public interest theory," which originated in Pigou's (1938) work in the 1930s. The basic idea is that unregulated markets will result in market failures that require the imposition of regulations. More recent research has questioned those insights (Coase, 1960). In particular, "public choice theory" has emphasized the negative effects of vested interests, rent seeking and regulatory capture (Tullock 1967, Stigler 1971, Peltzman, 1976).
} 
creative destruction and hamper economic development (Büttner 2006, Ciccone and Papaioannou 2006). ${ }^{2}$

A tax code is a particular configuration of regulations that can influence market entry through its direct and indirect effects. For instance, Gordon (1998) and Cullen and Gordon (2007) show that higher taxes have a distinct and significantly negative effect on entrepreneurship. ${ }^{3}$ Although previous studies examine how tax rates, the composition of tax codes and marginal effects influence entry by new firms, scarcely any research has been devoted to the influence of the administrative burden of taxes on market entry. Compliance with tax codes and tax policies is associated with costs in addition to the pure financial cost of the tax, which may also stifle entrepreneurship. As tax codes differ in their complexity, the time that is required to comply with such taxes also differs. Therefore, it may be assumed that tax codes impose a fixed cost on new firms and on entrepreneurs who are considering establishing a firm, thus creating a barrier to entry. This barrier could have significant welfare implications.

We use two sets of data compiled by the World Bank to address the issue of whether the administrative burden—rather than tax rates-influences entrepreneurship. We use data on new firm registration to measure the ease of market entry. From the World Bank's Ease of Doing Business dataset, we obtain indicators on the tax administrative burden (the time, procedures and effort required to comply with tax codes), the

\footnotetext{
${ }^{2}$ Gordon (2004) and Bosma and Harding (2007) claim that institutional differences explain the growth differences between Europe and the US. Geroski (1989) finds a positive relationship between entry and productivity growth. See also Evans and Jovanovic (1989), Hurst and Lusardi (2004), Alesina et al. (2005), Fiori et al. (2007), Djankov et al. (2007), Arnold et al. (2008), Djankov (2008) and La Porta (2008).

${ }^{3} \mathrm{~A}$ different but related issue is that a significant tax administrative burden should be expected to encourage entrepreneurs to devote more time to unproductive, or even destructive, activities rather than engaging in productive entrepreneurship (Baumol, 1990).
} 
corporate tax rate and proxies of the general business environment (costs of starting a business). These data have been used in a number of previous studies (e.g., Klapper et al. 2006, Klapper and Love, 2011). We also construct a proxy for the tax administrative burden through a principal component analysis of the time (hours) and the number of procedures required to comply with tax codes.

We argue that the tax administrative burden has an effect on market entry that is separate from both taxes on profits and from the more general business environment (entry barriers). For our most robust estimate, we find that the elasticity of entry with respect to the tax administrative burden is 0.3 . This finding implies that a 10 percent reduction in the tax administrative burden results in a 3 percent increase in entry rates.

2. Tax administrative burden: what are the regulatory costs associated with the tax system?

There is an extensive body of literature on the effects of taxes on entrepreneurship addressing the structure of taxes, the overall tax pressure, marginal tax rates and taxes on wealth. The results are somewhat inconclusive, but the overall conclusion of these studies appears to be that the effect of the level of individual taxes is ambiguous (sometime even positive), whereas increased marginal rates have a discernible negative effect on the propensity to become an entrepreneur. ${ }^{4}$ However, this effect on entrepreneurship is sensitive to the possibilities of arbitrage between tax bases (Gentry and Hubbard 2000, Parker and Robson 2003, Cullen and Gordon 2007). Tax structures

\footnotetext{
${ }^{4}$ See Hansson (2008) and Henrekson and Sanandaji (2011) for surveys.
} 
that lower opportunities for individual wealth accumulation, thereby adding to financial constraints, are also reported to have a negative effect on entrepreneurship (Evans and Jovanovic 1989, Banerjee and Newman 1993, Hansson 2008).

In a study by Djankov et al. (2010) examining effective corporate taxes for a standardized firm in 2004 in 85 countries, such taxes are found to have a considerable negative effect on investments (by incumbents and by foreign direct investment) and on entrepreneurial activity. A 10 percent increase in the corporate tax rate is shown to reduce the aggregate investment in relation to GDP by 2 percent and to reduce market entry by 2 to 5 percent. Furthermore, tax increases are negatively correlated with growth but positively associated with the growth of the informal sector.

A study by Djankov et al. (2010) also implements World Bank indicators pertaining to the tax administrative burden (time and procedures required to pay taxes) in addition to corporate taxes. The analysis focuses on the level of corporate taxes and implements three different versions of tax rates. The first version relates to the statutory corporate tax rate, whereas the remaining two aim to identify the effective corporate tax rate. More precisely, the effective tax rate accounts for all cost deductions and depreciations after one and five years in the second and third versions of the implementation, respectively. In addition to corporate tax variables, the analysis controls for other taxes (labor tax, personal income taxes, VAT, sales taxes and other taxes) and certain macroeconomic variables (inflation, openness, tax evasion and quality of institutions). The analysis results show that higher corporate taxes have a statistically significant negative effect on foreign direct investment (not on domestic investment). 
Djankov et al. (2010) also perform a number of robustness tests to analyze the effect of including a particular control variable on the corporate tax variables. The negative results from the corporate tax variables remain intact, and the results are found to be robust. Regarding the effects of tax administration, the two variables are included in separate regressions. Only the number of tax procedures is shown to negatively influence entrepreneurship (but has no effect on investments), whereas the time that is needed to comply with tax regulations is not significant. Adding a procedure reduces entry by approximately 0.3 percentage points.

Most economic analyses of tax systems focus on the effect of various tax rates and the efficiency and distributive effects of tax codes. Further, these analyses frequently focus on one single tax rate or tax rule and ignore the possibility of systemic effects associated with the tax system. From an economic perspective, there is reason to believe that the indirect effects of tax systems are significant. This shortcoming is important because most modern tax systems are highly complex. Little research has been conducted to examine the question of what the systemic effects of tax systems are, with the exception of Djankov et al. (2010) noted above. However, whereas Djankov et al. (2010) use tax administration as a control variable in two of the regressions, we are placing tax administration at the forefront of our analysis.

\section{Theoretical framework}


For our purposes, we use a simple model of entry in which taxes influence entry decisions directly by reducing after-tax profit and indirectly by increasing fixed costs 5 . The entry of new firms will continue as long as entrepreneurs expect a profit $\left(\pi_{n}\right)$ above the fixed operating costs $(F C)$. This model holds for both entrepreneurial new firms and incumbent firms. The entry of new firms will continue until the expected profit of one additional entrant is below the fixed costs. Thus, the $n+1$ entrant expects $\pi_{n}<F C$. This expectation yields the following condition, $\pi_{n} \geq F C>\pi_{n+1}$, which implies that a sufficient increase in fixed costs will reduce the number of firms in the market. Tax rates are relevant in this context because corporate tax rates reduce the after-tax profits, which is relevant to the entrepreneurial decision. Hence, we can express the entry equation as follows ${ }^{6}$ :

$E_{t}=\alpha\left(\pi_{t-1} *(1-\tau)-F C\right)$

where $\tau$ is the corporate tax rate. The administrative costs that are associated with tax compliance increase the fixed costs. For our purposes in this paper, we can identify two country-specific fixed cost components: 1) the tax administrative burden ${ }^{7}$ and 2) the entry costs that are related to the general business environment. Both types of countryspecific costs can be expected to reduce the market entry rate in a country. Because we consider cross-country market entry and use aggregate measures, we are interested in explaining only the country-specific components that may influence entry density. We

\footnotetext{
${ }^{5}$ For our purposes and given data limitations, we use a simple model of entry. For more sophisticated models (including dynamic) of entry, see Geroski (1991).

${ }^{6}$ For the sake of simplicity, we assume that all firms confront the same profit functions, such that the following holds in equilibrium: $\sum_{i=1}^{n} \pi_{i} \geq \sum_{i=1}^{n} F C_{i}$.

7 The fixed costs that are associated with tax administration can presumably be further divided into one transitory component and one permanent component. The transitory component represents a learning effect. Both types will reduce entry.
} 
include the corporate tax rate as a separate component in the model to emphasize that taxes on profits will also affect entry and must be controlled for when examining the effect of tax administrative burden.

\section{Data}

As a measure of entry, we use the number of new firm registrations per 1,000 inhabitants. The data are obtained from World Bank Group Entrepreneurship Snapshots (WBGES). To measure the tax administrative burden, we use two different measures: the number of tax payments per year and the time required to pay taxes. We also use information on corporate taxes as a share of profits and information on the cost of starting a business as a share of income per capita. This information on taxes and tax administration is collected from the World Bank Doing Business project. ${ }^{8}$ After combining all of the variables, we obtain an unbalanced panel covering 118 countries over a period of six years.

Both the number of tax payments per year and the time required to pay taxes may be assumed to reflect the underlying complexity of the tax code ${ }^{9}$. Therefore, we can use these two measures to derive a more comprehensive measure of the complexity of the tax system, which presumably reflects the administrative burden that the tax code imposes on firms. Thus, we conduct a principal component analysis to construct a third measure, which we refer to as the tax administrative burden.

\footnotetext{
${ }^{8}$ See World Bank (2013) for a description of the methodology and the assumptions used when compiling these data.

${ }^{9}$ There are several approaches to measuring legal complexity, such as the use of a type of network analysis based on graph theory (e.g., Bommarito and Katz, 2010). However, such an approach is practically inapplicable in a cross-country context and will fail to capture the qualitative content of tax legislation.
} 
We estimate regressions with entry density as the dependent variable and with the different measures of tax administrative burden as the main explanatory variables. Failing to control for variables that may be correlated with both the tax administrative burden and entry would lead to an overestimation of the effect. Thus, we also control for a number of factors that have previously been shown to be correlated with entry. First, the level of economic development as captured by the GDP per capita (constant 2005 US dollars) and the growth rate are included in the regressions. ${ }^{10}$ Second, we include total taxes as a share of profits to eliminate the possibility that the tax administrative burden simply reflects differences in overall tax rates. Finally, to ensure that the tax administrative burden is not simply a proxy for the general business environment (and therefore entry costs), a control for the overall quality of the business environment is included. Data may be obtained from the authors upon request. The variables are reported in table $1^{11}$

\section{Table 1. Data and variables}

\begin{tabular}{|l|l|}
\hline Number of tax payments & $\begin{array}{l}\text { Number of tax payments that a company must make per } \\
\text { year. Natural logarithm is used. }\end{array}$ \\
\hline Time to pay taxes & $\begin{array}{l}\text { Time that is needed to comply with tax law and pay } \\
\text { taxes. Natural logarithm is used. }\end{array}$ \\
\hline
\end{tabular}

\footnotetext{
10 The design of policies varies with the level of economic development of countries and influences the regulatory framework (van Stel 2005, Saxenian 2006 and Rodrik 2007).

${ }^{11}$ For a detailed description of the variables, see the data from the World Bank.
} 


\begin{tabular}{|c|c|}
\hline Tax administrative burden & $\begin{array}{l}\text { A proxy for tax administrative burden is obtained } \\
\text { through a factor analysis (principal component) of the } \\
\text { number of tax payments and the time to pay taxes. }\end{array}$ \\
\hline Tax rate & $\begin{array}{l}\text { Total corporate tax rate as a percentage of profits. } \\
\text { Natural logarithm is used. }\end{array}$ \\
\hline Entry & $\begin{array}{l}\text { Entry density measured as the number of new firms per } \\
1,000 \text { inhabitants by year. The data cover } 118 \text { countries } \\
\text { over the period from } 2006 \text { to } 2011 \text {. Natural logarithm is } \\
\text { used. }\end{array}$ \\
\hline Growth & Annual growth rate in GDP per capita. \\
\hline GDP/capita & GDP per capita in constant 2005 US dollars. \\
\hline Entry costs & $\begin{array}{l}\text { Cost of starting a business as a percentage of the share } \\
\text { of income per capita. }\end{array}$ \\
\hline
\end{tabular}

A concern with this approach may be that the inclusion of multiple variables that can be assumed to be interrelated may cause multicollinearity. For example, the tax administrative burden may be expected to vary positively with tax pressure, assuming that a higher tax rate implies a more complex tax system. However, this variation is not observed, and the correlation between our three measures of tax administrative burden and the total tax rate ranges from 0.18 to 0.25 . The correlations are reported in table 2 . 
Table 2. Correlation matrix

\begin{tabular}{|l|l|l|l|l|l|l|l|}
\hline & Payments & Time to & Tax & Tax & Entry & Growth & GDP per \\
& per year & pay & administrative & rate & & \\
\hline Payments per year & 1 & & & & & \\
\hline Time to pay & $0.31^{*}$ & 1 & & & & \\
\hline Tax administrative burden & $0.65^{*}$ & $0.69^{*}$ & 1 & & & \\
\hline Tax rate & $0.23^{*}$ & $0.25^{*}$ & $0.18^{*}$ & & & \\
\hline Entry & $-0.23^{*}$ & $-0.25^{*}$ & $-0.31^{*}$ & $-0.19^{*}$ & 1 & & \\
\hline Growth & $0.11^{*}$ & $0.10^{*}$ & $0.15^{*}$ & 0.06 & $-0.16^{*}$ & 1 \\
\hline GDP per capita & $-0.36^{*}$ & $-0.27^{*}$ & $-0.40^{*}$ & $-0.08^{*}$ & $0.28^{*}$ & $-0.26^{*}$ & 1 \\
\hline Entry costs & $0.12^{*}$ & 0.05 & $0.14^{*}$ & $0.23^{*}$ & -0.25 & $0.15^{*}$ & $-0.23^{*}$ \\
\hline
\end{tabular}

* indicates statistically significant correlation at the 5 percent level.

\section{Regression model}

In the first step, we estimate the following simple regression model, which is an empirical version of equation 1 :

$\ln \left(\right.$ Entry $\left._{j t}\right)=\alpha+\beta_{1}\left(\ln (\text { Tax adm.burden })_{j t}\right)+\beta_{2}(\ln ($ Tax rate $))+\beta_{3} \mathbf{X}_{j t}+\varepsilon_{j t}$

where $\mathbf{X}_{\mathrm{jt}}$ represents a vector of control variables for country $j$. We perform three types of estimations: 1) pooled OLS, 2) random effect with time effects and robust standard errors and 3) a fixed effects model with year effects and country-clustered standard 
errors. The results are reported in table 3 (the OLS results are not reported). The results are robust to the various specifications. Because of the panel structure of our dataset, we test for the appropriate panel specification. The Hausman test supports a fixed effect model. However, because of efficiency considerations, we omit the country effects and retain only the year fixed effects rather than choosing to use country-clustered standard errors. Furthermore, our explanatory variables account for a significant amount of the country heterogeneity.

Because several of our variables may be expected to be interrelated, multicollinearity may pose a problem. To eliminate the possibility of multicollinearity, we estimate the variance inflation factor (VIF). The results indicate that the VIF is never above two; thus, there is no multicollinearity problem in our study.

Our results show that the tax administrative burden does in fact impose a significant cost for new firms and that the tax administrative burden reduces the rate at which new firms are formed. All three of our measures of tax administrative burden are found to have a negative effect on new firm formation. The elasticity of tax administrative burden with respect to the entry rate is approximately 0.3 , which must be considered an economically significant effect. It is worth emphasizing that the measures of tax administrative burden are significant despite controlling for both the overall tax pressure (taxes as a share of profits) and the general measure of entry costs. As expected, the tax rate exerts a significant effect, and the elasticity with respect to the new firm entry rate is above 0.4 . Our control variables also account for significant effects, particularly concerning whether the broad measure of entry costs/barriers has a 
significant negative effect on entry. The results without control variables are reported in the appendix.

Table 3. New firm formation and tax administrative burden

\begin{tabular}{|c|c|c|c|c|c|c|}
\hline \multicolumn{7}{|c|}{ Dependent variable: $\ln$ Entry } \\
\hline & (1) & (2) & (3) & (4) & $(5)$ & (6) \\
\hline InPayments per year & $\begin{array}{l}-0.307^{*} \\
(0.170)\end{array}$ & & & $\begin{array}{l}-0.308^{* * *} \\
(0.047)\end{array}$ & & \\
\hline $\ln$ Time to pay & & $\begin{array}{l}-0.154^{* *} \\
(0.078)\end{array}$ & & & $\begin{array}{l}-0162^{* * *} \\
(0.031)\end{array}$ & \\
\hline $\begin{array}{l}\text { InTax administrative } \\
\text { burden }\end{array}$ & & & $\begin{array}{l}-0.278^{* *} \\
(0.114)\end{array}$ & & & $\begin{array}{l}-0.287^{* * *} \\
(0.023)\end{array}$ \\
\hline $\ln$ Tax rate & $\begin{array}{l}-0.482^{* * *} \\
(0.185)\end{array}$ & $\begin{array}{l}-0.485^{* * *} \\
(0.195)\end{array}$ & $\begin{array}{l}-0.427^{* *} \\
(0.195)\end{array}$ & $\begin{array}{l}-0.466^{* * *} \\
(0.081)\end{array}$ & $\begin{array}{l}-0.472^{* * *} \\
(0.073)\end{array}$ & $\begin{array}{l}-0.414^{* * *} \\
(0.085)\end{array}$ \\
\hline \multicolumn{7}{|l|}{ Controls } \\
\hline Entry cost & $\begin{array}{l}-0.211^{* *} \\
(0.091)\end{array}$ & $\begin{array}{l}-0.223^{* *} \\
(0.095)\end{array}$ & $\begin{array}{l}-0.216^{* *} \\
(0.092)\end{array}$ & $\begin{array}{l}-0.208^{* * *} \\
(0.068)\end{array}$ & $\begin{array}{l}-0.222^{* * *} \\
(0.073)\end{array}$ & $\begin{array}{l}-0.214^{* * *} \\
(0.068)\end{array}$ \\
\hline Growth & $\begin{array}{l}-0.070^{* * *} \\
(0.021)\end{array}$ & $\begin{array}{l}-0.075^{* * *} \\
(0.022)\end{array}$ & $\begin{array}{l}-0.072^{* * *} \\
(0.072)\end{array}$ & $\begin{array}{l}-0.047^{* * *} \\
(0.009)\end{array}$ & $\begin{array}{l}-0.052^{* * *} \\
(0.009)\end{array}$ & $\begin{array}{l}-0.049^{* * *} \\
(0.009)\end{array}$ \\
\hline GDP/capita & $\begin{array}{l}0.15-\mathrm{e} 4^{* *} \\
(0.000)\end{array}$ & $\begin{array}{l}0.18-\mathrm{e} 4^{* *} \\
(0.000)\end{array}$ & $\begin{array}{l}0.15-\mathrm{e} 4^{* * *} \\
(0.000)\end{array}$ & $\begin{array}{l}0.16-\mathrm{e} 4^{* * *} \\
(0.000)\end{array}$ & $\begin{array}{l}0.19-\mathrm{e} 4^{* * *} \\
(0.000)\end{array}$ & $\begin{array}{l}0.16-\mathrm{e} 4^{* * *} \\
(0.000)\end{array}$ \\
\hline
\end{tabular}




\begin{tabular}{|c|c|c|c|c|c|c|}
\hline Constant & $\begin{array}{l}3.217^{* * *} \\
(0.785)\end{array}$ & $\begin{array}{l}3.105^{* * *} \\
(0.951)\end{array}$ & $\begin{array}{l}2.084^{* *} \\
(0.777)\end{array}$ & $\begin{array}{l}3.056^{* * *} \\
(0.249)\end{array}$ & $\begin{array}{l}2.976^{* * *} \\
(0.463)\end{array}$ & $\begin{array}{l}1.924^{* * *} \\
(0.417)\end{array}$ \\
\hline Year effect & Yes & Yes & Yes & Yes & Yes & Yes \\
\hline $\begin{array}{l}\text { Country-clustered } \\
\text { standard errors }\end{array}$ & Yes & Yes & Yes & No & No & No \\
\hline Robust errors & No & No & No & Yes & Yes & Yes \\
\hline $\mathrm{R}^{2}$ & 0.38 & 0.37 & 0.38 & 0.37 & 0.36 & 0.37 \\
\hline No. of countries & 118 & 118 & 118 & 118 & 118 & 118 \\
\hline No. of observations & 597 & 593 & 593 & 597 & 593 & 593 \\
\hline VIF & 1.59 & 1.55 & 1.58 & 1.59 & 1.55 & 1.58 \\
\hline
\end{tabular}

$*^{* *}$ and ${ }^{* * *}$ indicate statistical significance at the 10,5 and 1 percent levels. Entry, time to pay taxes,

procedures to pay taxes, tax administrative burden and the tax rate are all natural logarithms. The tax administrative burden is determined through a principal component analysis of the number of tax payments per year and the time that is needed to comply with the tax law. The dependent variable is the natural log of entry density. The tax administrative burden variable was obtained through a principal component analysis of $\ln$ (payments per year) and $\ln$ (time to pay).

The regression results show that the difference between tax administrative burden and tax rates is not significant, implying that a 10 percent reduction in the tax administrative burden is equivalent to a 10 percent reduction in the tax rate. Thus, the negative effects caused by the complexity of the tax system are also significant in economic terms. 


\section{Conclusions}

The role of entrepreneurs and entrepreneurial activity in determining economic processes and development has been extensively researched. The market entry of new firms has also been researched extensively, and much work has been undertaken to identify both the effects of entry on economic activities and the determinants of such market entry. Similarly, much research exists on the effects of tax policy both on general economic activities and on new firm formation. However, there is scant research on the links between tax complexity, the administrative burden created by this complexity and new firm formation. In this paper, we find that the administrative burden that the tax system imposes on firms significantly reduces new firm formation. This subject has largely been neglected in the previous literature. We find that the tax administrative burden has a negative effect on market entry. Our most robust estimate indicates that the elasticity of entry with respect to the tax administrative burden is 0.3 , which implies that a reduction in the burden by 10 percent translates into a 3 percent increase in entry. The results are robust when we control for the general economic environment, taxes on profits and other forms of market entry barriers. These findings have important implications for tax policies throughout the world. Most assessments of tax policies are based on partial equilibrium assessments that ignore the wider consequences of administrative costs on new firm formation. Our findings suggest that the negative systemic effects of complex tax codes are overlooked in conventional tax policy assessments, and these findings imply that reductions in the complexity of the tax code would translate into higher rates of market entry for new firms. 


\section{References}

Aghion, P., Blundell, R., Griffith, R., Howitt, P and Prantl, S., (2006), The effects of entry on incumbent innovation and productivity, NBER WP 12027, Cambridge, Ma.

Ardagna, S. and Lusardi, A., (2009), Heterogeneity in the effect of regulation on entrepreneurship and entry size, NBER Working paper 15510, Cambridge, Ma.

Alberto Alesina \& Silvia Ardagna \& Giuseppe Nicoletti \& Fabio Schiantarelli, 2005.

"Regulation And Investment," Journal of the European Economic Association, MIT Press, vol. 3(4), pages 791-825, 06.

Baumol, W. J., (1990), Entrepreneurship: Productive, unproductive and destructive, Journal of Political Economy, vol. 89, no. 5, 893-821.

Bommarito, J. M. and Katz, D. M., (2010), A mathematical approach to the study of the United States Code, Physica A, vol. 389, 4195-4200.

Bosma, N. and Harding, R. (2007), Global Entrepreneurship Monitor: GEM 2006 Results, London Business School, London.

Büttner, B., (2006), Entry barriers and growth, Economics Letters, 93, 150-155.

Ciccone, A. and Papaionnou, E., (2007), Red tape and delayed entry, Journal of European Economic Association, 5(2-3), 444-458. 
Cullen, J. B. and Gordon, R. H., (2007), “Taxes and entrepreneurial risk-taking: Theory and evidence for the U.S." Journal of Public Economics, vol. 91, 1479-1505.

Djankov, S., La Porta, R., Lopez-de-Silanes, F. and Shleifer, A., (2002), The regulation of entry, Quarterly Journal of Economics, vol. 117, 1-35.

Djankov, S., Ganser, T., McLiesh, C., Ramalho, R. and Shleifer, A., (2010), "The Effect of Corporate Taxes on Investment and Entrepreneurship," American Economic Journal: Macroeconomics, vol. 2, no. 3, 31-64.

Evans, D. S. and Jovanovic, B., (1989), “An estimated model of empirical choice under liquidity constraints," Journal of Political Economy, 808-827, vol. 97, no. 4.

Fiori, G., Nicoletti, G., Scarpetta, S. and Schiantarelli, F., (2007), "Employment Outcomes and the Interaction Between Product and Labor Market Deregulation: Are They Substitutes or Complements?," Boston College Working Papers in Economics 663, Boston College Department of Economics, revised 08 Aug 2008.

Gentry, M. W. and Hubbard, R. G., (2000), Tax Policy and Entrepreneurial Entry, American Economic Review, vol. 90, no. 2, 283-287.

Geroski, P. A., (1991), Market Dynamics and Entry, Oxford, Blackwell. 
Geroski, P. A., (1989), Entry, Innovation and Productivity Growth, Review of Economics and Statisitcs, vol. 71, no. 4, 572-578.

Gordon, R. and MacKie-Mason, J. K., (1997), How much do taxes discourage incorporation? Journal of Finance, vol. 52, no. 2, 477-505.

Gordon, R. H., (1998), “Can high personal tax rates encourage entrepreneurial activity?” IMF Staff Papers 45, 49-80.

Gschwandtner, A. and Lambson, V. E., (2002), The effects of sunk costs on entry and exit: evidence from 36 countries, Economics letters, 77, 109-115.

Henrekson, M. and Sanandaji, T., 2011, "Entrepreneurship and the theory of taxation", Small Business Economics, 37, 167-185.

Hurst, E. and Lusardi A., (2004), "Liquidity Constraints, Household Wealth, and Entrepreneurship," Journal of Political Economy, 112(2), 319-347.

Orr, D., (1974), The Determinants of Entry: A study of Canadian Manufacturing Industries, Review of Economic and Statistics, vol. 56, 58-66.

Klapper, L. and Love, I., (2011), The Impact of Business Environment Reforms on New Firm Registration, World Bank 
Klapper, L., Laeven, L. and Rajan, R., (2006), “Entry regulation as barrier to entrepreneurship," Journal of Financial Economics, vol. 82, 591-629.

Nicoletti, G., and Scarpetta, S., (2003), Regulation, Productivity and Growth, World Bank policy research working paper 2944.

Parker, S.C. \& Robson, M. T., (2004), Explaining international variations in selfemployment Evidence from a panel of OECD countries. Southern Economic Journal 71(2): 287-301.

Peltzman, S., (1976), “Towards a more general theory of regulation,” Journal of Law and Economics, vol. 19, 211-240.

Pigou, A. C., (1938), “Money Wages in Relation to Unemployment”, EJ

Stigler, G. J., (1971), The Theory of Economic Regulation, Bell Journal of Economics and management Science, 137-146.

Wennekers, S., van Stel, A., Thurik R. and Reynolds, P., (2005), Nascent Entrepreneurship and the Level of Economic Development, Small Business Economics, vol. 24, 293-309.

Tullock, G., (1969), “Federalism: Problem of Scale, Public Choice, vol. 6., 19-30. 


\section{Appendix 1}

Table A1. New firm formation and tax administrative burden

\begin{tabular}{|c|c|c|c|}
\hline & (1) & (2) & (3) \\
\hline Payments per year & $\begin{array}{l}-0.732 \\
(0.160)\end{array}$ & & \\
\hline Time to pay & & $\begin{array}{l}-0.285^{* *} \\
(0.158)\end{array}$ & \\
\hline $\begin{array}{l}\text { Tax administrative } \\
\text { burden }\end{array}$ & & & $\begin{array}{l}-0.576^{* * *} \\
(0.142)\end{array}$ \\
\hline Constant & $\begin{array}{l}2.484^{* * *} \\
(0.496)\end{array}$ & $\begin{array}{l}1.791^{* *} \\
(0.863)\end{array}$ & $\begin{array}{l}0.223 \\
(0.153)\end{array}$ \\
\hline Year effect & Yes & Yes & Yes \\
\hline $\begin{array}{l}\text { Country clustered } \\
\text { std. errors }\end{array}$ & Yes & Yes & Yes \\
\hline $\mathrm{R}^{2}$ & 0.13 & 0.04 & 0.13 \\
\hline No. of countries & 118 & 118 & 118 \\
\hline No. of observations & 607 & 603 & 603 \\
\hline
\end{tabular}

$*, * *$ and ${ }^{* * *}$ indicate statistical significance at the 10,5 and 1

percent levels. Entry, time to pay taxes, procedures to pay taxes

and tax administrative burden are all natural logarithms. The tax

administrative burden is determined through a principal

component analysis of the number of tax payments per year and

the time that is needed to comply with the tax law (natural

logarithms). The dependent variable is the natural log of entry

density. 